Nig. J. Anim. Prod. 2017 44(1):185 - 191

(C) Nigerian Society for Animal Production

Nigerian Journal of Animal Production

\title{
Performance and nutrient digestibility of crossbred weaned pigs fed raw pride of barbados (Caesalpina pulcherrima) seed meal
}

Ogunbode, A. A., Baderinwa, A. F. and Gbemisola, I. O.

Department of Animal Production Technology,

Faculty of Animal and Fisheries Technology,

Oyo State College of Agriculture and Technology, Igboora, Nigeria.

Abstract Corresponding author e-mail aaogunbode@gmail.com

Deficit of conventional feed resources in meeting increased demand has led to hike in their prices culminating in soaring cost of livestock feed. This has necessitated the search for cheap and easily available alternatives. Pride of barbados seed which constitute a waste has potential of becoming a cheap and easily available feed resource. Performance and nutrient digestibility of dietary inclusion of raw pride of barbados seed meal was evaluated in an eight weekfeeding trial. A total of sixteen crossbred (Large White $x$ Landrace) weaned pigs of eight weeks of age were weighed and allotted to four dietary treatments with four pigs each being a replicate in a completely randomized design. Diet 1 (control) was without raw pride of barbados seed meal while 5\%, 10\% and 15\% of virgin raw pride of barbados were included in diets 2,3 and 4 respectively. Weekly weight gain, daily feed intake, feed conversion ratio and nutrient digestibility of raw pride of barbados seed meal was also determined. Results revealed a significant average final body weight of $16.75 \mathrm{~kg}$ (diet 3) to $24.50 \mathrm{~kg}$ (diet 4). The pigs fed 15\% raw pride of barbados had the highestfeed intake of $137.20 \mathrm{~kg}$ in diet 4 while the lowest feed intake was obtained in pigs fed 10\% (diet 3) inclusion level of raw pride of barbados. Pigs maintained on the control diet had the best feed conversion (7.60kg) while the pigs fed diet 3 had the lowest feed conversion ratio (8.93kg). Crude protein, ether extract and dry matter digestibility was highest at T4 $(84.15 \%, 80.21 \%$ and $86.70 \%)$ respectively while the least values $(68.71 \%, 65.75 \%$ and $71.10 \%$ was obtained in T2 and T3 respectively. This study concluded that 15\% inclusion of raw pride of barbados in the diets of crossbred weaned pigs had no deleterious effect on performance and nutrient digestibility of pigs.

Keywords: Antinutritional factors, nutrient digestibility, performance, pride of barbados, raw, weaned pigs.

\section{Introduction}

Pigs are prolific monogastric species which have great ability in converting feed to animal products. Their production has therefore been advocated as a short term measure toward alleviating the animal protein and energy deficit especially where there are no religious taboos preventing their production and consumption (Kalla et al., 2003). Pig production in particular represents one of the fastest ways of increasing animal protein since pigs grow at a faster rate and are highly more prolific than cattle, sheep and goats. In growth rate, pig is only surpassed by broilers (Holness,
2005). Apart from their high rate of reproduction, pigs are characterized by the efficiency of nutrient transformation into high quality animal protein. However, the high cost of the conventional feedstuff most especially protein supplement, necessitated the quest for locally available alternatives that can substitute for the conventional feedstuffs economically by reducing feeding cost, thereby making pig enterprise a more profitable one. There is need for greater utilization of the relatively neglected leguminous seeds particularly the pride of barbados (Caesalpina pulcherrima) abundant locally, compare 


\section{Crossbred weaned pigs fed raw pride of barbados (Caesalpina pulcherrima) seed meal}

their nutritive values to the traditional feed resources for feed formulation in order to reduce escalating cost of monogastric animal production (Adeola and Olukosi, 2008). These feed sources are however not fully and appropriately integrated into livestock feed, this may be as a result of very little knowledge of their potential as feed materials, the presence of antinutritional substances as well as lack of proper knowledge of storage capabilities especially over long periods (Ben et al., 2002). Pride of barbados is one of the common names of a small evergreen perennial shrub. It is a leguminous plant belonging to the leguminosae family, which is the second largest family among dicotyledons (Burton, 1985). This shrub originates from the tropical West Indies and has alternate, bipinnately divided leaves. The family is made up of approximately 650 genera and 1800 species, divided into three sub-families; caesalpineae, mimoseae and papilionaceae. Its species are found in temperate, humid tropics and highland, savanna and lowland zones (Dutta, 1981). Pride of barbados flowers throughout the year and is usually 10 to 15 feet high. As a legume, it has pods that split into two parts to release dry and brown mature seeds. Pride of barbados is planted as an ornamental tree for shade and to control erosion. They produce large quantities of pods containing seeds which are wasted at each production season. There is also no competition between man and animals for pride of barbados. This study therefore was designed to investigate the effect of feeding graded levels of raw pride of barbados seedmeal on the performance and nutrient digestibility of crossbred weaned pigs.

\section{Materials and methods}

Experimental location

The experiment was carried out at the piggery unit of the Teaching and Research Farm of the Oyo State College of Agriculture and Technology, Igboora. The experimental area lies within $7^{0} 15$ North and $3^{\circ} 30$ East of equator with an average rainfall of $1278 \mathrm{~mm}$ and average annual temperature of $27^{\circ} \mathrm{C}$.

\section{Experimental diet}

Mature and ripen pods of pride of barbados were collected within Igboora environment. Seeds that were from dried and matured pods were removed and ground into pride of barbados seed meal using hammer mill. The meals produced were used to formulate four isocaloric and isonitrogenous diets.

\section{Experimental animals and management}

A total of sixteen crossbred (Large White $\mathrm{x}$ Landrace) weaned pigs in their eight weeks of age was purchased from reputable commercial pig farm in Ibadan. The animals were quarantined for one week during which they were treated against ectoparasites using ivermectin solution $(0.5 \mathrm{~mL} / 5.0 \mathrm{~kg}$ body weight) and injected intramuscularly with penstrep antibiotic at $(0.5 \mathrm{~mL} / 5.0 \mathrm{~kg}$ body weight $)$. The animals were offered feed twice daily at $08.00 \mathrm{a} . \mathrm{m}$ and $02.00 \mathrm{p} . \mathrm{m}$. The feed were offered at $4 \%$ of their body weight as feed per day at the start of the experiment and increased as the animals were advancing in age while water was supplied ad libitum. The animals were housed in concrete floored pen with walls made of concrete blocks up to $2 \mathrm{~m}$ high under intensive management system. The pens and equipment used were thoroughly washed and disinfected with morigald. The pens were equipped with inbuilt watering and feeding facilities. The experiment lasted for eight weeks.

\section{Proximate analysis}

The experimental diets were analysed for crude protein (CP), crude fibre (CF), ether extract (EE), and ash contents using 


\section{Ogunbode, Baderinwa and Gbemisola}

A.OA.C (2005) official methods of analyses. The nitrogen free extract (NFE) contents of the diets were obtained by difference.

\section{Feed intake measurement}

Feed intake was measured daily for all the treatment groups. Feeds were weighed before each feeding period. The leftovers of the feeds were collected and weighed to determine the quantity consumed (daily feed intake).

\section{Measurement of body weight}

The animals were weighed weekly in the mornings before they were served experimental diets. Records of these weekly weights were kept throughout the experimental period and were used to assess the body weight gain and feed conversion ratio.

\section{Digestibility trial}

Metabolic trial was conducted when the weaned pigs were 112 days to determine the apparent nutrient digestibility of the diets. Two pigs per treatment making a total of eight pigs were randomly selected and house separately in metabolic cage. The pigs were acclimatized for two days prior to the commencement of five days metabolic trial. A known weight of feed was fed to the pigs housed in individual metabolic cages. Excreta collected per pig per day for five days were oven dried $\left(70^{\circ} \mathrm{C}\right)$ and bulked. Pooled samples of feed and dried faecal samples were used for proximate analysis according to procedure (McDonald et al., 2002)

\section{Statistical analysis}

Data obtained were subjected to analysis of variance (ANOVA) of statistical analysis software (SAS, 2012). Significant means were separated using Duncan Multiple Range Test at $5 \%$ level of probability.

\section{Results and discussion}

The performance characteristics of the crossbred weaned pigs fed diets containing graded levels of raw pride of barbados seed meal are shown in Table 2. The effect of treatments on average final body weight was significantly $(\mathrm{P}<0.05)$ different across the treatment. The results showed that average final body weight $(24.50 \mathrm{~kg})$ was highest at $15 \%$ raw pride of barbados seed meal inclusion in the diet while the lowest $(16.75 \mathrm{~kg})$ was in $10 \%$ raw pride of barbados seed meal inclusion. This may be attributed to the fact that the quantity of antinutritional factors, tannin, phytate, oxalate and saponin present in the seed were enough to extend negative effect on the side of animals. Aganga and Adolga (1999) reported that tannin inhibit the activities of digestive enzymes and decrease protein quality by reducing digestibility and palatability. Phytate had been reported to form compound with anions and proteins thus making the protein unavailable for enzymatic activities leading to poor growth (Akinmutimi, 2004). FAO, (1990) advocated that phytate binds calcium, iron, zinc and other minerals thereby reducing their availability in the animal body. Nkafamiya et al. (2007) opined that oxalate decreased calcium absorption and aiding the formation of kidney stones. Saponin reduce the uptake of certain nutrients including glucose and cholesterol at the gut through intraluminal physiochemical interaction (Ologhobo, 2012). The average daily feed intake and average daily weight gain followed the same trend as the average final body weight. The average daily weight gain of pigs fed $5 \%$ and $15 \%$ was significantly $(\mathrm{P}<0.05)$ higher than that of pigs fed $10 \%$ raw pride of barbados. The crude fibre in the $15 \%$ raw pride of barbados seed meal based diet is below the limits (20\%) reported by McDonald et al. (2002) as the highest level of crude fibre in the diet of simple stomached animals. Moreover, the positive effect of dietary fibre cannot be undermined. Dietary fibre had been found 


\section{Crossbred weaned pigs fed raw pride of barbados (Caesalpina pulcherrima) seed meal}

Table 1: Gross composition of experimental diet

\begin{tabular}{lllll}
\hline Ingredients & T1 & T2 & T3 & T4 \\
\hline Maize & 30.00 & 28.00 & 25.00 & 20.00 \\
Maize offal & 25.00 & 25.00 & 25.00 & 25.00 \\
Raw pride of Barbados seed meal & 0.00 & 05.00 & 10.00 & 15.00 \\
Soyabean meal & 20.00 & 17.00 & 15.00 & 15.00 \\
Palm kernel cake & 20.00 & 19.00 & 19.00 & 19.00 \\
Local fish meal & 1.25 & 2.25 & 2.25 & 2.25 \\
Bone meal & 3.00 & 3.00 & 3.00 & 3.00 \\
Salt & 0.50 & 0.50 & 0.50 & 0.50 \\
Vit. Min. premix & 0.25 & 0.25 & 0.25 & 0.25 \\
TOTAL & 100.00 & 100.00 & 100.00 & 100.00 \\
DETERMINED ANALYSIS & & & & \\
Dry matter (\%) & 91.06 & 90.40 & 91.71 & 91.19 \\
Moisture (\%) & 8.94 & 9.60 & 8.29 & 8.81 \\
Crude Protein (\%) & 18.90 & 19.05 & 19.10 & 19.25 \\
Crude Fibre (\%) & 5.00 & 8.70 & 10.00 & 13.23 \\
Ash (\%) & 5.20 & 5.01 & 5.30 & 5.10 \\
Ether extract (\%) & 5.00 & 4.50 & 4.60 & 6.00 \\
Nitrogen free extract (\%) & 56.96 & 58.14 & 53.71 & 55.84 \\
Digestible energy (Kcal/kg) & 3.326 & 3.601 & 3.507 & 3.480 \\
\hline
\end{tabular}

Table 2: Performance characteristics of weaner pigs fed raw pride of barbados seed meal

\begin{tabular}{llllll}
\hline Parameters & T1 & T2 & T3 & T4 & SEM \\
\hline Initial weight $(\mathrm{kg})$ & 7.75 & 7.75 & 7.75 & 7.75 & 0.00 \\
Final weight $(\mathrm{kg})$ & $23.25^{\mathrm{ab}}$ & $23.5^{\mathrm{ab}}$ & $16.75^{\mathrm{c}}$ & $24.50^{\mathrm{a}}$ & 1.52 \\
Feed intake $(\mathrm{kg})$ & $115.70^{\mathrm{c}}$ & $123.70^{\mathrm{b}}$ & $100.30^{\mathrm{d}}$ & $137.20^{\mathrm{a}}$ & 6.68 \\
Feed conversion ratio (FCR) & 7.60 & 7.85 & 8.93 & 8.25 & 0.25 \\
Average weight gain $(\%)$ & $15.75^{\mathrm{bc}}$ & $6.25^{\mathrm{ab}}$ & $9.00^{\mathrm{d}}$ & $16.75^{\mathrm{a}}$ & 1.58 \\
\hline
\end{tabular}

$\mathrm{a}, \mathrm{b}, \mathrm{c}, \mathrm{d}$; means on the same row with different superscripts are significantly different $(\mathrm{p}<0.05)$.

Table 3: Nutrients digestibility of weaner pigs fed raw pride of barbados seed meal diets $(\mathrm{Mg} / \mathrm{Kg})$

\begin{tabular}{llllll}
\hline Parameters & $\mathbf{1}$ & $\mathbf{2}$ & $\mathbf{3}$ & $\mathbf{4}$ & SEM \\
\hline Crude protein (\%) & $80.69^{\mathrm{b}}$ & $68.71^{\mathrm{d}}$ & $76.80^{\mathrm{c}}$ & $84.15^{\mathrm{a}}$ & 2.77 \\
Ash (\%) & $60.80^{\mathrm{a}}$ & $60.00^{\mathrm{a}}$ & $53.43^{\mathrm{b}}$ & $45.00^{\mathrm{c}}$ & 3.21 \\
Crude fibre (\%) & $53.60^{\mathrm{b}}$ & $56.33^{\mathrm{a}}$ & $51.99^{\mathrm{c}}$ & $50.40^{\mathrm{d}}$ & 1.17 \\
Ether extract (\%) & $79.91^{\mathrm{c}}$ & $66.60^{\mathrm{b}}$ & $65.75^{\mathrm{d}}$ & $80.21^{\mathrm{a}}$ & 4.27 \\
Dry matter (\%) & $86.00^{\mathrm{a}}$ & $74.10^{\mathrm{b}}$ & $71.10^{\mathrm{c}}$ & $86.70^{\mathrm{a}}$ & 3.39 \\
Digestible energy (kcal/kg) & $80.71^{\mathrm{c}}$ & $90.40^{\mathrm{ab}}$ & $90.25^{\mathrm{d}}$ & $94.07^{\mathrm{a}}$ & 2.57 \\
Moisture content (\%) & $20.09^{\mathrm{c}}$ & $33.40^{\mathrm{ab}}$ & $34.27^{\mathrm{b}}$ & $20.00^{\mathrm{a}}$ & 2.74 \\
Nitrogen free extract (\%) & $195.09^{\mathrm{a}}$ & $185.04^{\mathrm{b}}$ & $181.53^{\mathrm{b}}$ & $179.76^{\mathrm{c}}$ & 3.30 \\
\hline
\end{tabular}

$\mathrm{a}, \mathrm{b}, \mathrm{c}, \mathrm{d}$; means on the same row with different superscripts differ significantly $(\mathrm{p}<0.05)$. 


\section{Ogunbode, Baderinwa and Gbemisola}

to activate the intestine, enhance peristaltic movement and ensure more enzyme production thereby resulting in efficient digestion of nutrients (Esonu et al., 1997).Raw pride of barbados contains high fibre, its inclusion in the diets at $15 \%$ level did not result in increased dietary fibre such a situation would have led to the dilution of other nutrients thereby leading to increased feed intake. Pigs eat to meet their energy requirements and to sustain rapid growth and development. The energy needs of the weaned pigs were therefore satisfied even at $15 \%$ raw pride of barbados inclusion hence the pigs did not consume more feed than those on the control diet (Esonu et al., 2004). Pigs with the lowest feed intake had the lowest weight gain. Njoku et al. (2013) opined that sufficient offering of feed to pigs is vital in optimizing overall growth performance. The feed conversion ratio (FCR) of pigs fed $10 \%$ and $15 \%$ raw pride of barbados was significantly $(\mathrm{P}<0.05)$ higher than that of pigs fed $5 \%$ diet. Pigs fed $0 \%$ raw pride of barbados seed meal had comparable $(\mathrm{P}<0.05)$ feed conversion ratio with those fed $5 \%, 10 \%$ and $15 \%$ raw pride of barbados seed meal. The feed conversion ratio was not significantly $(\mathrm{P}>0.05)$ influenced with the increasing levels of raw pride of barbados seed meal. The pigs on diet 1 (control) had the least numerical value and the best feed conversion ratio since the lower the feed conversion ratio, the more the value of the diet (Ogbonna et al., 2001) hence, pigs fed with diet containing higher level of inclusion did not utilize the feed better than the maize based diet as they required more feed per unit weight gain. The result of the nutrient digestibility of crossbred weaned pigs fed diets containing graded levels of raw pride of barbados seed meal is presented in Table 3. The result of crude protein, crude fibre, ether extract, ash, nitrogen free extract and dry matter were significantly $(\mathrm{P}<0.05)$ different among the treatment means. The digestibility of crude protein was higher in T4 but differ significantly $(\mathrm{P}<0.05)$ from the other treatments and the least was recorded in $\mathrm{T} 2$ but differ $(\mathrm{P}<0.05)$ statistically from the other treatments. Pigs fed T4 had the highest ether extract value while the least value was obtain in pigs maintained on T3. The nitrogen free extract was better in the control diet compared to all other treatments. The dry matter digestibility was higher in $\mathrm{T} 1$ and $\mathrm{T} 4$ which were similar but significantly $(\mathrm{P}<0.05)$ differed from the other treatments. The reduction in nutrient utilization in weaned pigs may be ascribed to the presence of anti-nutritional substances in the diets. This finding is in agreement with the earlier report by Ihekoronye and Ngoddy (1985) who opined that some of these active principles interfere with digestive process thereby preventing efficient utilization of the legume protein. As the raw pride of barbados seed meal level increased, there was a dilution effect of fibre on the diets reducing the utilization of other nutrient in the body of the animals. This reduced nutrient digestibility and intake of raw pride of barbados seed meal inclusion could go a long way to reduce the actual protein intake and also lead to a lower resultant body weight gain of pigs as raw pride of barbados inclusion increased

\section{Conclusion}

It was therefore concluded that raw pride of Barbados can be included in the diets of crossbred weaned pigs up to $15 \%$ level without any detrimental effect on the performance and nutrient digestibility of weaned pigs.

\section{References}

Adeola, O. and Olukosi, O. A. 2008. Opportunities and challenges in the 
Crossbred weaned pigs fed raw pride of barbados (Caesalpina pulcherrima) seed meal

use of alternative feedstuffs in poultry production. Nigerian Poultry Science Journal, 5 (4): 147-155

Aganga, A. A. and Adogla-Bessa, T. 1999. Dry matter degradation, Tannin and crude protein content of some indigenous browse plant of Botswania.Grewia retinevis. Arch Zootech, 48, 79-83

Akinmutimi, A. H. 2004. Evaluation of sword bean (Canavalia gladiata) as an alternative feed resources for broiler chickens $\mathrm{PhD}$ Thesis, College of Animal Science, $\mathrm{M} \mathrm{i} \mathrm{c} \mathrm{h} \mathrm{a} 1 \quad O \mathrm{k} \mathrm{p}$ a $\mathrm{a}$ University of Agriculture, Umudike, Nigeria

AOAC, 2005. Association of Official Analytical Chemists.Official Methods of Analysis $16^{\text {th }}$ ed.Washington DC,Arlington

Ben Salem, H., Atti, N., Prillo, A. and Nefzauoi, A. 2002. Polyethylene glycol in concentrate or feed blocks to deactivate condensed tannins in Acacia cyanophylla Linl forage.1. Effects on intake, digestion and growth by barbine lambs. Anim. Sci, 75:127-135

Burton, B. T. 1985. Types of Legumes In: Heinz Handbook of Nutrition. $2^{\text {nd }}$ edition.AVI Publishers, USA, 61-62

Duncan, D. B. 1955. New Multiple Range Test Biometrics, 11:1-42

Dutta, A. C. 1981. Importance of plant to life In: Botany for Degree Students. $2^{\text {nd }}$ (ed). Guaheti Publishers, New York, 634-733

Esonu, B. O., Azubuike, J. C., Emenalon, O. O., Etuk, E. B., Okoli, I. C., Ukwu, H. O. and Nneji, C. S. 2004 . Effect of enzyme supplementation on the performance of broiler finisher fed
Microdesmis pubercula leaf meal. International Journal of Poultry Science, 3: 112-114

Esonu, B. O., Etuk, E. B. and Ezeigbo, O. C. 1997.Determination of optimal dietary level of soybean (Glycine $\max (1)$ Merill) hulls for broilers. Journal of Technical Education in Nigeria 2 (1 and 2): 76-82

FAO, 1990. Determination of phytate content in raw Lima beans. Document Repository Rome, Italy

Holness, D. H. 2005. Pigs. The Tropical Agriculturalist, CTA (The Technical Centre for Agricultural and Rural Co-operation).Editors : Rene Coste and Anthony J. Smith).Revised Ed. Macmillan Publishers Ltd, Oxford,152pp

Ihekoronye, A. and Ngoddy, P. 1985. Proteins :Food quality control. In:Integrated Food Science Technology $3^{\text {rd }}$ (ed). Macmillan Publishers,London, 28:155-193

Kalla, D. J. U., Habu, P. F. and Barrie, G. 2003. Analysis of swine production at Kent Academy,Plateau state, Nigeria. Tropical Journal of Animal Science, 6(2):79-84

McDonald, P. M., Edwards, R. A. and Greenhaigh, J. F. D. 2002. Animal Nutrition $6^{\text {th }}$ (ed) Singapore Longman, Singapore Publishers Printed Ltd Pp 154-176

Njoku, C. P., Aina, A. B. J., Sogunle, O. M., Adeyemi, O. A and Oduguwa, O. O. 2013. Evaluation of feed quantity offered, feeding frequency and duration of feeding on the performance of growing pigs. Thai Journal of Agricultural Science 46 (4) : 181-190

Nkafamiya, I. I., Manji, A. J., Modibbo, U. and Umaru, H. A. 2007. African Journal of Biotechnology $6(19): 2461-2463$ 


\section{Ogunbode, Baderinwa and Gbemisola}

Ogbonna, J. U., Ogundola, F. I. and Oredein, A. O. 2001. Effect of wet feed on cockerel chicken performance. Nigerian Journal of Animal Production, 1:52-55

Ologhobo, A. D. 2012. Feed Biohazards:life destroyers and life enhancers. An inaugural lecture delivered at the University of Ibadan on $6^{\text {th }}$ September, 2012
SAS, 2012. SAS Institute Inc., SAS

Campus Drive,Cary, North Carolina, USA
Received: $25^{\text {th }}$ August, 2016 Accepted: $12^{\text {th }}$ March, 2017 